\title{
日本建築学会構造系論文集ならびに 日本建築学会計画系論文集執筆要領
}

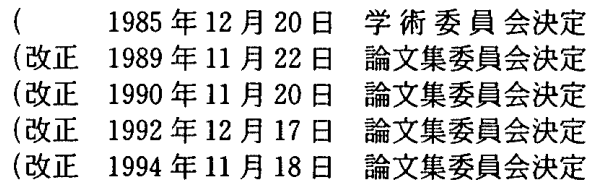

(1985 年12月 20 日 学術委員会决定 論文集委員会決定

(改正 1994 年11月18日
1985 年 12 月 21 日 実施) 1990 年 4 月 1 日 実施) 1991 年 1 月 1 日 実施) 1993 年 4 月 1 日 奏施) 1994 年 12 月 11 日 実施)

\section{1. 原稿投稿の形態と登載料}

（1）原稿（本文・要約を含む）は版下原稿を原則と するが，レイアウト原稿を受け付ける。

（2）版下原稿とは，そのまま製版できるように割り 付けした原稿であり，本会所定の原稿用紙（版下 原稿）を使用し，ワードプロセッサ等で執筆し，版下 用図・表・写真等を貼り込んだもの。

（3）レイアウト原稿とは，次の条件に沿って作成した 原稿。

a) 本会所定原稿用紙又はその㹡大コピーしたもの （A3判を上限とする）を使用する

b）査読用原稿においては，各頁の字数および図表 の大きさは版下原稿と同一大するが, 図表等 (コ ピー）は任意位置に挿入してよい。

c）文字は手書きでもよい。 ただし，明瞭に記載する。

d）図・表・写真は版下原稿となるものを作成する こと。

e）採用決定後の最終レイアウトは刷上り論文と同一 とすること。

\begin{tabular}{|c|c|c|c|c|}
\hline$\frac{\text { 内容 }}{\text { 論文 }}$ & 頁数*1 & 版下原稿 & レイアウト原稿 & 備 \\
\hline \multirow[t]{2}{*}{ 論文 } & 6 & $10,000 \mathrm{~A}$ & $30.000 \mathrm{M}$ & 基準頁 \\
\hline & $\begin{array}{r}7 \\
8 \\
9 \\
10 \\
\end{array}$ & $\begin{array}{c}\text { 1頁当り } \\
20.000 \mathrm{P} \\
\text { を加算 }\end{array}$ & $\begin{array}{c}\text { 1頁当り } \\
20,000 \text { 用 } \\
\text { を加算 }\end{array}$ & $\begin{array}{l}\text { 超過頁 } \\
\text { 4頁を限度とする }\end{array}$ \\
\hline 討論 & 2 & 無 料 & 20,000 円 & 基淮頁 \\
\hline
\end{tabular}

*1) 書き方種別 B， C の場合 (2.(1)参照), 英文また は和文要約が所定頁以内であれば，この頁に 算定しない。

2. 原稿の書式・規格と論文等の構成

(1) 書き方種別と頁数

論文および質疑討論の書き方種別と頁数は以下の通 りとする。

\begin{tabular}{|c|c|c|c|c|c|c|}
\hline \multirow{2}{*}{ 区分 } & 書き方 & 本文 & 要約 & 本文·英文要旨・ & 英・和文要約 & \multirow[t]{2}{*}{ 超過頁 } \\
\hline & 種 別 & 種別 & 種別 & キーワード基準頁 & 頁 & \\
\hline \multirow{3}{*}{ 論文 } & A & 和文 & なし & 6 頁以内 & $\overline{-1}$ & 4 頁以内 \\
\hline & B & 和文 & 英文 & 6 頁以内 & 2 頁以内 & 4 頁以内 \\
\hline & C & 英文 & 和文 & 6 頁以内 & 2 頁以内 & 4 頁以内 \\
\hline \multirow{2}{*}{ 討論 } & $\mathrm{D}$ & 和文 & なし & 2 頁以内 & - & 認めない \\
\hline & $\mathrm{E}$ & 英文 & なし & 2 頁以内 & & 認めない \\
\hline
\end{tabular}

[ 注 ] 各記入項目の字数・語数の制限は各項目の項を参照す ること。

（2）原稿規格と組み方

a) 所定原稿用紙にはB 4 判とA4 判があり,この
原稿用紙 1 枚が論文集の 1 頁に相当する。

b) 原稿の記入枠 (太枠)外には原稿を記入してはな らない。

なお，第 1 頁最上欄の「発行年月日」「通し ハンブル」および論文末尾の「受理日・採用決定 日」は採用決定後，本会で貼り付ける。

c） 1 頁は和文の本文相当で 2,400 字とし，本文は 2 段組を原則とする。1 行あたり 25 文字で 1 頁は 48 行， 2 段組，段間は 2 字あきとする。 (25 文字 $\times 48$ 行 $\times 2$ 段 $=2,400$ 字)。

第 1 頁目は表題氏名・英文要旨・キーワード・ 所属機関等の記載分だけ本文記入が削減され る。各記入枠の取り方は 3.4.5.6. で説明する。

d）書き方種別 C・E (英文) およびBの英文要旨の場 合の文字数・行数換算方法は, 1 頁あたり, 680 語とし，本文は 1 段組を原則とする。

\section{(3) 論文の構成}

論文の構成は下記による。質疑討論はこれに準じる。 論文原稿は，この構成に従い，「版下原稿執筆の手 引き」とそれに揭載している記入例を参照して記入 すること。

a) 表題亡氏名

b) 英文要旨 (Abstract)

c) キーワード (Keywords)

d）所属機関・学位 (1 頁目下欄)

e) 本文 (本文は図・表・写真を含め, 下記を標準 亡する)

イ.まえがき (Introduction)

口. 本 論 (Body)

八. 結 語 (Conclusion)

二. 謝 辞 (Acknowledment)

f) 付録 (Appendix)，注（Notes）および参考文 献 (References)

j) 英文要約（Summary）または和文要約（書き 方種別 B·C の場合のみ)

\section{3. 表題と氏名}

（1）表題は書き方種別 A，B，D のときには，和文表 題を先に, その下行に英文表題を, 表き方種別 C, Eのときには英文表題を先に，その下行に和文表題 を記載する。氏名の場合も同様順序とする。

（2）大会学術請演会または支部発表研究会に発表し た研究, その他研究発表会, シンポジウム, 一般的に 公表されていない報告書などにおいて発表のもの 
は,その発表場所・時期を注記する。

（3）表題は論文および質疑討論の内容を具体的に表 現したものとする。

（4）共通する主題のもとに連続する数編を執筆する 場合，表題は個々の論文内容を表現するものとし， 総主題はサブタイトルとして，その1，その 2 などを 付す。応募規程 3 を参照。

（5）表題・氏名欄等の取り方は以下の通りとする。

a)「通しノンブル」「発行年月日」の貼り付け欄とし て先頭の本文相当 2 行を空白行とする。

b) 表題および氏名欄は第 2 行目から概ね 15 行目 までの範囲で，上下に十分な空白行を取って割 り付ける。

c) このうち, 表題と氏名の間は 2 行程度の空白行 を設ける。なお，本欄は字体の統一のため，当 分の間本会において版を作り直すので，十分な 行数を確保すること。

\section{4. 英文要旨}

論文の内容の主要な点を 100 ワード以内に簡潔に䌆め, 刷上り本文の前に添える。

英文要旨の原稿の組み方に関しては [手引] 3.(2)を 参照すること。

5. キーワード

キーワードは学術用語集から 3 6 語 (英文 Keywords, 和文 Keywords）を選択する。 キーワードの原稿の組み方に関しては［手引］3.(3)を参 照すること。

\section{6. 所属機関・学位}

論文の発表者全員の所属機関, 職位, 学位（和文名, 英文名）を明記する。

所属機関・学位の原稿の組み方に関しては [手引 3 . (5)を参照すること。

7. 本, 文

（1）本文の畫き方

a) 文章および数式は明暸に記入する。

b) 和文の文体は口語体とし，原則として常用漢 字・新かなづかいを用い，用語はなるべく文部 省学術用語（建築学編）とする。

c) ローマ字，アラビア数字，ギリシャ文字，上ツキ，下 ッキ，大文字，小文字な県まぎらわしいものは 特に注意を払うこと。

d）図・表・写真に横に，原則として本文は組まな い。

d）本文の文字の大きさは [手引] 3.(3)を，原稿 の組み方に関しては[手引３３.(4)を参照する こと。

(2) 数式

a) 数式には, (1), (2), (3)なよ゙と通し番号を付す。

b）添字は論文の刷上り時に見える大きさとする。

（3）図・表・写真

a) 版下原稿作成

(1)「版下原稿方式」「レイアウト原稿方式」の両方と も版下原稿を作成する。
(2)図表「版下原稿方式」の場合は直接掲載位置に 貼り込み，「レイアウト原稿」の場合は原稿用紙 割り付け用の大きさにコピーしたものを貼る。 写真はコピーを本原稿へ貼り付け, 写真(プリント) の裹面に代表者を記入したもの 1 枚を別添す る。祅フィルムは受け付けない。

カラー写真をモノクロとして使用する場合は, 明 暗がはっきりしないことがあるので注意する。

(3)「レイアウト原稿」の場合は図・表・写真の版下 原稿を最終提出時に提出する。

(4)写真の中に直接説明が入る場合は, 写真に直接 タイプ文字を貼り込む。

(5)図・表の文字と記号等は印刷上がりの大きさ (B5 判) で十分に判読できる大きさでなけれ ばならない。

b) 表題と通し番号

(1)図・表・写真には，内容を明確に表す表題を必 ず付けること。

(2)書き方種別 B の場合の図表等の表題は英文で 記載すること。英文表題の書き方は, 初語の頭 文字のみを大文字とし, その他は小文字を用い る。ピリオドは省略する。

(3)表題には, 図・表・写真ごとに通し番号を付け る。この時, 章ごとに分けずに，図 1, 図 2, 一, 表 1 , 表 $2, \cdots$, 写真 1 , 写真 $2, \cdots$, などと記 入する。英文表題の場合は, Fig. 1, Fig. 2, ․, Table 1, Table 2, $\cdots$, Photo 1, Photo 2, $\cdots$, などと記入する。

(4)表題記入位置は,図・表・写真の場合その直下, 表の場合はその值上とする。

c) 組み方

図・表・写真の組み方に関しては [乎引] 3. (4)を参照すること。

8. 注および参考文献

（1）注および参考文献は，本文の後にそれぞれを使 用順に番号を付け，まとめて揭載する。

注および参考文献の文字の大きさおよび原稿組み方 に関しては [手引] 3.(6)を参照すること。

(2) 注および参考文献の番号は, 本文中の引用箇所 に肩付け11,2)のように明記する。

（3）参考文献の記載方法は以下の通りである。

a. 論文等の場合「著者名: 表題, 誌名, Vol, No. , 掲載ページ, 発行年月」の順とする。

b. 単行本の場合「著 (編) 者名: 書名, 発行所名, 発行年」の順となる。

c. 著者名は必ず姓名で記す。著者が多い場合には， 筆頭者以外は「ほか○名」で省略することもで きる。

d． 欧文の場合には，筆頭者は姓を先に記す。また， 連名者は「et al.」で省略することもできる。

e. 発行年月は, 原則として西暦で「1995.1」 「1995.2」のように記す。

（4）一般に公表されていない文献，たとえば未発表 
の論文，簡易印刷（コピーしたものなど）の委員会 報告や社内報告および私信などは，文献としてあつ かわない。必要があれば注とし，引用箇所に肩つ き(注1)袄21，のように明記する。

（5）図・表・写真などの引用・転載にあたっては, 著者自身が原著者などの著作権所有者の許可をとら なければならない。

(6) 記載例

参考文献

1）佐藤武夫，川島定雄，三木 韶：音響透過に関 する実験（第 3 報）材料に対する音の投射角之 遮音効果, 建築学会論文集, 大会号, 第 1 号, pp. 210 217, 昭和 11 年 3 月

2）内田祥三：木造仕口の実験的研究，建築学会論 文集, 第 2 号, pp. $21 \sim 30$, 昭和 11 年 7 月

3）中村達太郎：日本建築語彙 丸善, 明治 39 年, 新増補版 昭和 31 年

4) Luco. J.E. and Westmann, R.A. : Dynamic Response of Circular Footings, Journal of the Engineering Mechanics, ASCE, Vol.97, pp. 1381-1395, 1971. 4

注

注 1)「大工頭中井家文書」（史学第 37 巻第 1 号 第 46 巻第 1 号) 105 によると, 紫重右衛門 が中井大和守の配下で勘定方を担民してい たことがわかる。また長香寺寄託中井家文 書に「慶長十五年十九年, 駿河御用少々記」 と題する留帳があり，その中の「駿河御城 大工作料方にて渡手形之覚」は慶長 15 年 11 月 15 日に中井信濃守が作料を請取った旨を 紫重右衛門, 村伊右衛門に宛てた覚書の写 しで，この両名が中井家の勘定を担当して いたことを示している。

（7）注および参考文献記入後の論文の末尾に原稿受 理・採用決定年月日記載用に 2 行程度の空白を取る (この欄は本会で作成する)。

\begin{tabular}{|c|c|c|c|c|}
\hline \multirow{3}{*}{ 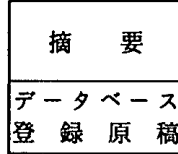 } & \multicolumn{3}{|c|}{ 原稿 の提 出種 類 } & \multirow{2}{*}{ 備 } \\
\hline & 新規原䅌 & 改訂原稿 & 最終原稿 & \\
\hline & $\begin{array}{c}3 \text { 枚 } \\
(コ ヒ ゚ ー)\end{array}$ & $\begin{array}{c}3 \text { 枚 } \\
(コ ヒ ゚ ー)\end{array}$ & $\begin{array}{c}1 \text { 枚 } \\
(ホ リ シ+n)\end{array}$ & \multirow[b]{2}{*}{$\begin{array}{l}\text { 最終原稿以外はコピーでよし } \\
\text { 原稿の右下枠外の[原稿番号 } \\
\text { 闌] に頁数を記入する。 }\end{array}$} \\
\hline & $\begin{array}{c}3 \text { 部 } \\
(\text { コピー) }\end{array}$ & $\begin{array}{c}3 \text { 部 } \\
(コ ヒ ゚ ー)\end{array}$ & 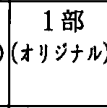 & \\
\hline $\begin{array}{l}\text { 查読㫪に対する } \\
\text { 回答書 }\end{array}$ & 不要 & $\begin{array}{c}3 \text { 部 } \\
(コ ヒ ゚ ー)\end{array}$ & 不要 & \begin{tabular}{|l} 
再查読の判定を行った各々查 \\
読書に対する回答で, 查読 \\
が 2 通の場合は 2 通提出す \\
る。修正意見付採用の埸合は \\
不要
\end{tabular} \\
\hline 原 馠 受領 書 & 1 呚 & 不要 & 不要 & \begin{tabular}{|l} 
「連絡先の住所，氏名」「論文 \\
の表題」を記入する。
\end{tabular} \\
\hline 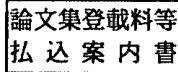 & 1 枚 & 不要 & 不要 & $\begin{array}{l}\text { 「別刷部数」「支払種別」「払込 } \\
\text { 方法」等を記入する。 }\end{array}$ \\
\hline 受 付シ - r & 1 枚 & 不要 & 不要 & $\begin{array}{l}\text { カデリー区分，研究部門，細分 } \\
\text { 類，揭载希望系列，表題，連 } \\
\text { 絡先などを記入する。 }\end{array}$ \\
\hline
\end{tabular}

\section{9. 英文要約または和文要約}

（1）原稿書き方種別が，B またはＣの場合は，英文 要約または和文要約を論文の末尾に付ける。

（2）英文要約は 1,200 語以内とする。また，和文要 約は 4,500 字以内とする。

（3）要約中には図表を挿入せず，本文図表の参照引 用にとどめる。

10. データベースへの登録について

採用された論文および質疑討墖は，所定のデータシート により学術情報センターのデータベースに登録する。

（1） データベース著作権は, 本会および学術情報センター の共有とする。

（2）本データベースは国内外において検索できる。

11. その他

（1）原稿提出にあたり，次の確認を行う。

a) 論文，質疑討論の原稿之関連書類は，下記の要 領に沿って作成したものを提出する。

（2）不備な原稿等の返却

論文応募規程, 本執筆要領, 版下原稿執筆の手引き の下記に示す事項を守っていない論文は事務的に返 却する。

a）既発表の論文（論文応募規程 1.（1）a）およ び2. 参照)。

b）連続した論文の先の編の查読が終了していない もの（論文集応募規程 3. 参照）。

c）応募資格者以外が著者になっているもの（論文 集応募規程 4. 参照)。

d）本会所定の原稿用紙以外のもの（本要領 1.(1) (2)(3) 参照)。

e）頁数制限を超過したもの（本要領 2.(1) 参照)。

f) 原稿の記入枠・行数・字数等の規格と組み方を 守っていないもの (本要領 2.(2)(3)参照)。

g) 図・表・写真等が版下原稿として作成されてい ないもの, および不鮮明なもの(本要領 1.(2)(3), 執筆の手引き2.(1)(3)参照)。

h)「版下原稿」の場合, 本文・注 - 参考文献の文 字の大きさと種別が適切でないもの，および印 字が不鮮明なもの（執筆の手引き $2 .((1)(3)$ 参 照)。

i) 提出原稿の部数・添付書類等の不備なもの（本 要領 11.(1) 参照)。

(3) 校正

a）版下原稿の場合には, 組み直した 1 頁目のみ著 者校正を行う。

b) レイアウト原稿の場合にはは，全頁の著者校正を 行う。

（4）原稿の返却

論文集刊行後に「版下原稿」の返却を希望する場合 は，その旨明記し，返送用封筒（角 2 封筒，郵送料 相当分切手添付）を，論文集の発行月の月末までに 本会編集事業課あて送付する。

期日までに，上記の返却手続きのない原稿は破棄す る。 